\title{
Nutritive value and apparent digestibility of bee-collected and bee-stored pollen in the stingless bee, Scaptotrigona postica Latr. (Hymenoptera, Apidae, Meliponini)
}

\author{
Pedro Guilherme FERNANDES-DA-SILVA ${ }^{\mathrm{a}}$, José Eduardo SERRÃo ${ }^{\mathrm{b} *}$ \\ a Departamento de Biologia, Instituto de Biociências, Universidade Estadual Paulista, \\ P.O. Box 199, 13506-900 Rio Claro, SP, Brazil \\ b Departamento de Biologia Geral, Universidade Federal de Viçosa, \\ 36571-000 Viçosa, MG, Brazil
}

(Received 28 June 1998; revised 9 March 1999, accepted 30 August 1999)

\begin{abstract}
In Meliponini bees, pollen is stored inside the hive. We compared the nutritional value and apparent digestibility of bee-collected and bee-stored pollen of Scaptotrigona postica. The results showed no differences in nutritional value and apparent digestibility between bee-collected and beestored pollen, suggesting that the storage process of pollen grains do not play a role in these parameters. These results are discussed in relation to other aspects of pollen storage, such as food conservation and/or organoleptic properties of stored pollen.
\end{abstract}

digestion / hypopharyngeal gland / Meliponini / pollen / stingless bee

\section{INTRODUCTION}

Scaptotrigona postica is an eusocial bee that lives in perennial colonies and stores pollen in pots inside the hive [18]. In others bee species, stored pollen is commonly associated with microorganisms, that supposedly play a role in conversion of pollen into a more easily digestible food for the bees, and in preservation of the food against attack by fungi and other deleterious microorganisms [7, 11, 16, 20, 25, 28].

However, Herbert and Shimanuki [12] suggested that the nutritive value of pollen for both bee-collected and bee-stored was identical, at least in Apis mellifera. The aim

\footnotetext{
* Correspondence and reprints
}

E-mail: jeserrao@mail.ufv.br 
of the present study was to investigate whether pollen stored in pots of Scaptotrigona postica has the equivalent nutritional value and apparent digestibility as pollen collected from the corbiculae of the bees when they arrive at the hive.

\section{MATERIALS AND METHODS}

\subsection{Insect bioassays and modes of pollen gathering}

The bees used (Scaptotrigona postica Latr.) were newly emerged adult workers from combs placed in a wooden box $(18.3 \times$ $18.3 \times 4.3 \mathrm{~cm})$ with a glass lid and maintained at temperature of $28 \pm 1{ }^{\circ} \mathrm{C}$, and 60 to $70 \%$ relative humidity. Each experimental group was maintained in wooden boxes $(11 \times 11 \times 8 \mathrm{~cm})$ with glass lids under the same environmental conditions as above. The pollen diet, water and $30 \%$ sucrose solution were supplied ad lib. inside each box. Diet, water and sucrose solution were changed on alternate days.

Three colonies were kept indoors in the apiary of the Department of Biology, UNESP, Rio Claro, Brazil were used to collect pollen. The pollen was collected in two ways. Corbicular pollen was collected through an aperture in the translucent tube that connected each hive with the exterior (Fig. 1). Any bee carrying something in the corbiculae was captured in the entrance tube by the aid of a catching tube and placed in a refrigerator $\left(0^{\circ} \mathrm{C}\right)$, and then pollen was removed from the corbiculae. If something other than pollen (e.g. resin) was carried by a bee it was discarded. Samples of stored pollen were taken directly from closed pots, inside each hive. These pots were filled and darker in color, which are assumed to be old pots.

During 7 days (5 to 11 September 1996) pollen from the corbiculae was collected, and stored pollen was collected on the 7 th day. Then two experimental groups were formed (control group fed with stored

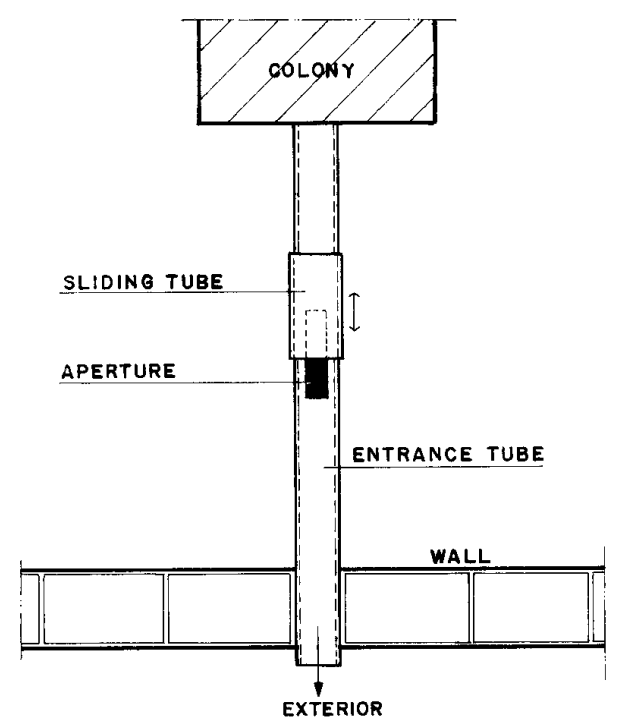

Figure 1. Entrance tube, with aperture of where bees carrying the corbicular pollen were collected.

pollen, and experimental group fed with corbicular pollen) for each colony, with 10 bees in each group.

The bees were allowed to feed for 8 days, after which they were fixed in $4 \%$ paraformaldehyde solution until dissection. This 8-day interval was shown to be the most effective based on earlier data [6-8, 27].

\subsubsection{Nutritive value of pollen grains}

The nutritive value of each treatment was determined based on the development of the hypopharyngeal glands (HPG), a parameter commonly used for this type of analysis $[4,7,8,27,29]$. For this, the bees were dissected in $70 \%$ alcohol under a stereomicroscope and the HPG were stained with $4 \%$ acetic carmine for $3 \mathrm{~min}$. Analysis of HPG was done by measuring the area of 10 acini cells selected at random for each bee $[4,7,8,27,29]$. The acini cells were measured in an AxioHome ${ }^{\mathrm{TM}}$ light microscope with the aid of Impact ${ }^{\mathrm{TM}}$ program. In this way 100 acini cells were examined for 
each group and each colony, totaling 300 acini cells per treatment.

\subsubsection{Digestibility of pollen grains}

The condition of pollen digestion was analyzed inside the rectum because it is largely known that digestive and absorptive events take place at the midgut level of insects (see Terra [26] for review). Thus in the rectum, nutrient digestion and absorption do not occur and pollen grains present in this gut region are free of enzymatic degradation.

The same bees used for analysis of HPG were analysed for apparent digestibility of the pollen grains. After dissection, the rectum was isolated from the gut and its wall disrupted with aid of forceps. The rectum content was stained 5 min with methylene blue and transferred to a slide with a drop of glycerin jelly.

The pollen grains in these preparations were examined in the same microscope noted above, to analyze the status of their apparent digestibility inside the rectum, following classification from Cruz-Landim and Serrão [5], where pollen grains are divided in: 1) completely intact; 2) with its content disorganized, retracted in the center of the grain; 3) empty but with the covers unbroken and 4) the covers broken.

Some light micrographs of pollen grains were obtained from corbiculae and storage pots following the treatment described above.
For both types of analysis (nutritive value and apparent digestibility), the data were pooled for statistical analysis by the MannWhitney U-test, with the level of significance set at $5 \%[13,24]$.

\section{RESULTS}

For colony 1, the pollen collected from the corbiculae seems to be statistically superior, in nutritive value, to the stored pollen (Tab. I). In the other colonies, both pollen were statistically similar in nutritive value on basis in the size of HPG acini.

Pollen grains in the rectum were classified as a) non-digested, when they were filled with dense content, and b) digested pollen, when they were empty or with their content retracted in the center of the grain leaving a clear periphery (Fig. 2). Analysis of the pollen grains into the rectum of the workers showed three pollen morphologic types (A, B and C), which are illustrated in Figure 2. Types $\mathrm{A}$ and $\mathrm{C}$ of pollen grains were observed in the rectum of both control and experimental groups of the three colonies. Type B was observed only into the rectum of the control groups of colonies 1 and 3 . However, type B pollen grains were never observed in the condition digested. Therefore, for our analysis, only the types A and $\mathrm{C}$ were considered.

In preliminary studies we observed that pollen grains from storage pots were almost all filled with dense contents (about 90\%),

Table I. Mean size of hypopharyngeal gland acini, in bees fed on stored pollen from pots inside the hive (control group) and bees fed on pollen taken from the corbiculae (experimental group).

\begin{tabular}{lccc}
\hline Colony & 1 & 2 & 3 \\
\hline $\begin{array}{l}\text { Control group } \\
\left(\mu \mathrm{m}^{2} \pm \mathrm{SD}\right)\end{array}$ & $2038.30 \pm 318.15^{\mathrm{a}}$ & $2139.74 \pm 686.90^{\mathrm{a}}$ & $2295.80 \pm 290.40^{\mathrm{a}}$ \\
$\begin{array}{l}\text { Experimental group } \\
\left(\mu \mathrm{m}^{2} \pm \mathrm{SD}\right)\end{array}$ & $2638.10 \pm 336.47^{\mathrm{b}}$ & $1788.28 \pm 614.20^{\mathrm{a}}$ & $2502.50 \pm 511.32^{\mathrm{a}}$ \\
\hline
\end{tabular}

Means followed by the same letter did not differ statistically $(p>0.05)$; Mann-Whitney test. 


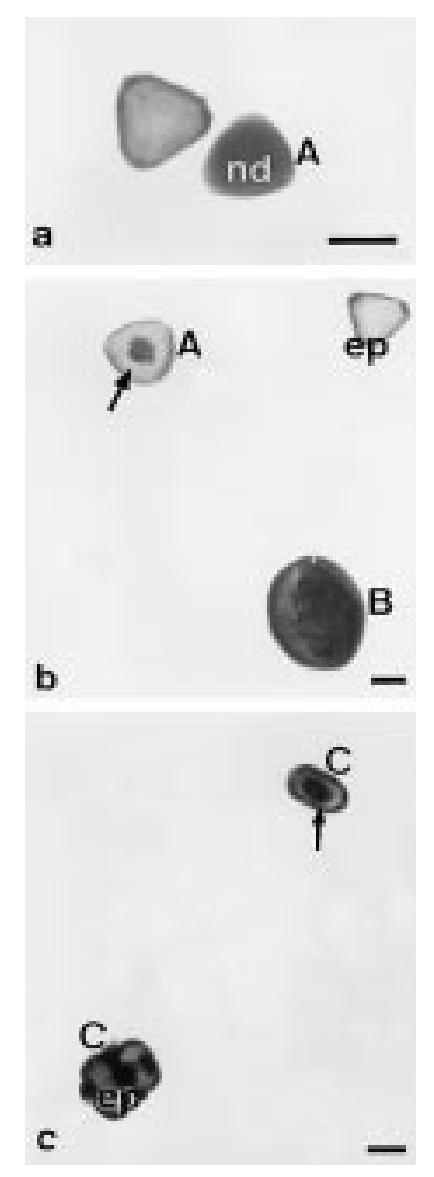

Figure 2. Light photomicrographs of the pollen grains in the rectum. a) Type A pollen grains in the non-digested condition (nd); b) Types A and $B$ pollen grains showing empty pollen grains (ep) and pollen with content disorganized and retracted in the center (arrow); c) Type C pollen grains in the same digestion condition, showed in 2a. Bars $=5 \mu \mathrm{m}$.

suggesting that digestion did not occur in the storage pots. The few pollen grains which were empty likely resulted from pollen grains that were broken when workers masticated and molded pollen lumps into a compact pollen mass during pollen manipulation and storage, not as result from digestive process into the pots. This process of pollen manipulation has been described for several bee species and is summarized by Roubik [20].

The apparent digestibility of pollen grains in the rectum of bee workers is summarized in Table II. For the three colonies, there were no significant differences between the amounts of digested pollen in the control vs. experimental groups. The non-digested condition of the pollen showed statistical differences between the groups only in colony 2 in which a slightly greater amount of filled pollen was present in the control group.

\section{DISCUSSION}

In Apis mellifera stored pollen undergoes a process of lactic acid fermentation [2] and seems to have an associated microflora [9] suggesting that microorganisms are involved in this process [12, 25]. For Meliponini, an association with some bacteria also seems to occur, at least for some species of Melipona spp. [11, 16], Plebeia sp., Trigona sp., Frieseomelitta sp., Leurotrigona sp., Tetragona sp., Nannotrigona sp. [16] and Trigona hypogea [10]. However, T. hypogea is an obligate necrophagous species that never stored pollen grains [1, 19, 22]. In A. mellifera, the association of stored pollen with microorganisms is believed to be responsible for fermentation or pre-digestion of stored food, and it is thought that these processes helps in enhancing the digestibility of pollen through production of some enzymes by the microorganisms $[11,16]$. This association also may contribute to the pollen's acquisition of certain organoleptic properties, which are specific for each bee species [7, 28]. Among other factors, these microorganisms could produce chemicals such as fatty acids and antibiotics that inhibit competing organisms and serve to enhance preservation of stores in tropical environments [10, 11].

To our knowledge, only one report [12] exists that compares the nutritive value of stored pollen (called "bee-bread") with the 
Table II. Mean percentages of pollen conditions in the rectum of bee workers, as an indicator of digestibility. "non-digested" = grains with dense content; "digested" = empty or nearly clear grains.

\begin{tabular}{|c|c|c|c|c|c|c|}
\hline \multirow{2}{*}{$\begin{array}{l}\text { Pollen } \\
\text { condition } \\
(\% \pm S D)\end{array}$} & \multicolumn{2}{|c|}{ Colony 1} & \multicolumn{2}{|c|}{ Colony 2} & \multicolumn{2}{|c|}{ Colony 3} \\
\hline & Control & Experimental & Control & Experimental & Control & Experimental \\
\hline Non-digested & $7.56 \pm 4.60^{\mathrm{a}}$ & $7.60 \pm 2.84^{\mathrm{a}}$ & $9.58 \pm 2.84^{\mathrm{a}}$ & $6.32 \pm 3.37^{b}$ & $9.80 \pm 3.37^{\mathrm{a}}$ & $6.95 \pm 4.52^{\mathrm{a}}$ \\
\hline Digested & $92.36 \pm 4.50^{a}$ & $92.20 \pm 4.20^{\mathrm{a}}$ & $90.32 \pm 2.84^{\mathrm{a}}$ & $93.60 \pm 3.38^{\mathrm{a}}$ & $91.12 \pm 3.14^{\mathrm{a}}$ & $93.35 \pm 4.67^{a}$ \\
\hline
\end{tabular}

Means followed by the same letter did not differ statistically $(p>0.05)$; Mann-Whitney test.

nutritive value of bee-collected pollen, and this report refers to A. mellifera. According to our results, the storage of pollen seems to be of no importance in changing the nutritive value of pollen, which is in agreement with the results obtained by Herbert and Shimanuki [12] for A. mellifera.

The presence of pollen grains, either nondigested or with their content disorganized and retracted at the center, has been observed in adult and larvae of Apini and Meliponini [3, 5, 23]. As suggested by Klungness and Peng [14], pollen grains in these conditions have a wall composed of cellulose and sporopollinin and presumably, these pollen species would be of less nutritive value to the bees. This agrees with work of Maurizio [17] and Louveaux [15] who observed that pollen of different species have different nutritional value to the workers A. mellifera. However, we observed that pollen grains of the same morphological type (see Fig. 2) can exist in three conditions: non-digested, digested partially or empty. This may be due to the time of pollen residence within the gut. Research by Serrão and Cruz-Landim [23] and Klungness and Peng [14] indicates that pollen digestion is a complex mechanism that involves physical and chemical changes in the pollen cover by enzymatic action, after which digestive enzymes can enter the pollen grains. Hence, pollen digestion should depend to a variable extent on both pollen species and the length of time inside the gut.
Although pollen digestion by $S$. postica is not complete, we believe that the bees must profit from ingested pollen, because their HPG's acini are well developed, in agreement of reports by Cruz-Landim and Akahira [4] and Fernandes-da-Silva and Zucoloto [7]. The absence of a significant difference between digested pollen grains in the control and experimental groups suggest that storage of pollen inside the colony does not affect pollen digestion by the midgut of bees. Gilliam et al. [11] demonstrated that microorganisms present into the storage pots of pollen produce enzymes such as aminopeptidases, lipases, proteases and phosphatases, which could contribute to pollen digestion, enhancement or convertion. Alternatively, it has been suggested that pollen digestion occurs inside the midgut of bees by the action of digestive enzymes release by digestive cells $[3,5,14$, $21]$. For $S$. postica, the results presented here are in agreement with this latter hypothesis, because pollen grains from storage pots were nearly always filled.

Further, one could suggest that the storage process would change the composition of pollen walls to facilitate pollen digestion. However, the results presented here showed that pollen grains obtained from corbiculae of foragers bees are not statistically different in their apparent digestibility when compared with pollen obtained from storage pots.

Although storage of pollen appear to play no role in pollen digestion or its nutritive 
value, this process may aid in preservation of the food and/or to contribute to the organoleptic properties of pollen as suggested by various authors [7, 10, 11, 16, 28]. However more detailed studies such as microbiological and chemical analysis of floral, corbicular and stored pollen, are necessary to test the validity of this hypothesis.

Résumé - Valeur nutritive et digestibilité apparente du pollen récolté et du pollen stocké par l'abeille sans aiguillon Scaptotrigona postica Latr. (Hymenoptera, Apidae, Meliponini). Chez les Meliponini, le pollen est stocké dans des pots à l'intérieur de la ruche. Plusieurs auteurs [7, $11,16,20,25,28]$ ont suggéré que le stockage du pollen augmentait sa digestibilité, facilitant ainsi l'absorption des nutriments par les abeilles. Pourtant, une seule étude [12] a comparé la valeur nutritive du pollen stocké et du pollen récolté et elle portait sur Apis mellifera. Le but de ce travail est de faire la comparaison pour Scaptotrigona postica.

Durant une période de sept jours, le pollen récolté a été prélevé sur les corbicules des abeilles (pelotes). À la fin des sept jours le pollen stocké à été prélevé dans les pots fermés à l'intérieur de la ruche. Dix ouvrières récemment écloses ont été nourries pendant 8 jours soit avec du pollen de pelotes, soit avec du pollen stocké. Le développement des acini des glandes hypopharyngiennes (Tab. I) et l'état de digestion des grains de pollen du rectum (Tab. II) ont été analysés. Les résultats suggèrent que le stockage du pollen dans la ruche n'a aucune influence sur la digestibilité des grains de pollen et n'entraîne donc pas de plus grande valeur nutritive. Ces résultats sont en accord avec ceux de Herbert et Shimanuki [12]. Le processus de stockage joue vraisemblablement un rôle dans la préservation du pollen stocké contre les microorganismes nuisibles et doit contribuer aux propriétés organoleptiques du pollen.

digestion / glande hypopharyngienne / Meliponini / pollen / abeille sans aiguillon
Zusammenfassung - Nährwert und Verdaulichkeit von gesammeltem und eingelagertem Pollen bei der stachellosen Biene Scaptotrigona postica Latr. (Hymenoptera, Meliponinae). Bei den Meliponinen wird der Pollen in Töpfen im Nest aufbewahrt. Mehrere Autoren [7, 11, 16, 20, 25, 28] haben angenommen, dass die Speicherung den Pollen leichter verdaulich macht, also die Aufnahme von Nährstoffen durch die Bienen erhöht. Nur in einer Arbeit [12] wurde der Nährwert von eingelagertem mit dem von frisch gesammeltem Pollen verglichen, allerdings wurde diese Arbeit mit Apis mellifera durchgeführt. Das Ziel dieser Untersuchung ist der Vergleich des Nährwerts von eingelagertem mit frisch gesammeltem Pollen bei Scaptotrigona postica.

Über einen Zeitraum von 7 Tagen wurde der frische Pollen aus den Körbchen (Höschen) gesammelt. Der eingelagerte Pollen wurde am Ende der 7 Tage aus verschlossenen Töpfen aus dem Nest gewonnen. Zehn frisch geschlüpfte Bienen wurden 8 Tage lang entweder mit Pollen der Höschen oder mit eingelagertem Pollen gefüttert. Danach wurden die Entwicklung der Hypopharynxdüsen und die Pollenkörner aus dem Enddarm analysiert. Bei den Hypopharynxdüsen wurden die Größe der Acini (Tab. I) und bei den Pollen der Grad der Verdauung (Tab. II) ermittelt.

Die Ergebnisse legen nahe, dass die Lagerung des Pollen im Nest keinen Einfluss auf die Verdaulichkeit der Pollenkörner und somit auf einen besseren Nährwert hat. Dies Ergebnis stimmt mit den Versuchen von Herbert und Shimanuki überein [12]. Wahrscheinlich spielen die Vorgänge bei der Einlagerung eher bei der Konservierung des Pollens gegenüber schädlichen Mikroorgansimen eine Rolle, oder sie tragen zu den geruchlichen oder geschmacklichen Eigenschaften des Pollens bei.

Verdauung / Hypopharynxdrüsen / Meliponini / Pollen / stachellose Bienen 


\section{REFERENCES}

[1] Camargo J.M.F., Roubik D.W., Systematics and bionomic of the apid obligate necrophages: The Trigona hypogea group (Hymenoptera, Apidae, Meliponinae), Biol. J. Linn. Soc. 44 (1991) 13-19.

[2] Chevtchik V., Mikrobiologie pylového kvǎsení, Publ. Fac. Sci. Univ. Masaryk 323 (1950) 103-130.

[3] Cruz-Landim C., Avaliação fotográfica da digestão do pólen presente no intestino de operárias de Apis mellifera L (Hymenoptera, Apidae), Naturalia 10 (1985) 27-36.

[4] Cruz-Landim C., Akahira Y., Influência da alimentação no desenvolvimento de algumas glândulas de Trigona (Scaptotrigona) postica Latreille (Hymenoptera - Apoidea), Pap. Avulsos Dep. Zool. (São Paulo) 19 (1966) 63-78.

[5] Cruz-Landim C., Serrão J.E., The evolutive significance of pollen use as protein resource by Trigonini bees (Hymenoptera, Apidae, Meliponinae), J. Adv. Zool. 15 (1994) 1-5.

[6] Dias L.B.L., Simões D., Relação entre estrutura etária (normal e anormal) de colônias de Scaptotrigona postica Latreille e desenvolvimento glandular (Hymenoptera: Apoidea), in: CruzLandim C., Hebling N.I., Lello E., Takahashi C.S. (Eds.), Homenagem à WE Kerr, Faculdade de Filosofia Ciências e Letras, Rio Claro, 1972, pp. 135-142.

[7] Fernandes-da-Silva P.G., Zucoloto F.S., A semiartificial diet for Scaptotrigona depilis Moure (Hymenoptera, Apidae), J. Apic. Res. 29 (1990) 233-235.

[8] Fernandes-da-Silva P.G., Muccillo G., Zucoloto F.S., Determination of minimum quantity of pollen and nutritive value of different carbohydrates for Scaptotrigona depilis Moure (Hymenoptera, Apidae), Apidologie 24 (1993) 73-79.

[9] Gilliam M., Microbiology of pollen and bee bread: the genus Bacillus, Apidologie 10 (1979) 269-274.

[10] Gilliam M., Buchman S.L., Lorenz B.J., Roubik D.W., Microbiology of the larval provisions of the stingless bee, Trigona hypogea, an obligate necrophage, Biotropica 17 (1985) 28-31.

[11] Gilliam M., Roubik D.W., Lorenz B.J., Microorganisms associated with pollen, honey, and brood provisions in the nest of a stingless bee, Melipona fasciata, Apidologie 21 (1990) 89-97.

[12] Herbert E.W., Shimanuki H., Chemical composition and nutritive value of bee-collected and bee-stored pollen, Apidologie 9 (1978) 33-40.

[13] Hollander M., Wolfe D.A., Nonparametric Statistical Methods, John Wiley and Sons, New York, 1973.
[14] Klungness L.M., Peng Y.S., A histochemical study of pollen digestion in the alimentary canal of honeybees (Apis mellifera L), J. Insect Physiol. 30 (1984) 511-521.

[15] Louveaux J., Le rôle du pollen dans l'alimentation de la ruche, Ann. Nutr. Aliment. 17 (1963) 313-318.

[16] Machado J.O., Simbiose entre as abelhas sociais brasileiras (Meliponinae, Apidae) e uma espécie de bactéria, Cienc. Cult. 23 (1971) 625-633.

[17] Maurizio A., Pollenernährung und Lebensvorgänge bei der Honigbiene (Apis mellifica L.), Landw. Jb. Schweiz 68 (1954) 115-182.

[18] Michener C.D., The Social Behavior of the Bees, Belknap Press Harvard Univ. Press, Cambridge, Massachusetts, 1974.

[19] Roubik D.W., Obligate necrophagy in a social bee, Science 217 (1982) 1059-1060.

[20] Roubik D.W., Ecology and Natural History of Tropical Bees, Cambridge University Press, New York, 1992.

[21] Schumaker T.T.S., Cristofoletti P.T., Terra W.R., Properties and compartmentalization of digestive carbohydrases and proteases in Scaptotrigona bipunctata (Apidae, Meliponinae) larvae, Apidologie 24 (1993) 3-17.

[22] Serrão J.E., Cruz-Landim C., Gut structures in adult workers of necrophagous neotropical stingless bees (Hymenoptera: Apidae: Meliponinae), Entomol. Gen. 19 (1995) 261-265.

[23] Serrão J.E., Cruz-Landim C., Microscopic observations of the digestion condition of pollen grains in the midgut of stingless bee larvae, J. Hymenopter. Res. 5 (1996) 259-263.

[24] Siegel S., Estatística não Paramétrica, McGrawHill, São Paulo, 1975.

[25] Sommeijer M.J., Bruijn L.L.M., Intranidal feeding, trophallaxis, and sociality in stingless bees, in: Hunt J.H., Nalepa C.A. (Eds.), Nourishment and Evolution in Insect Societies, Westview Press/Oxford \& IBH Publishing Co Pvt Ltd, Oxford, 1994, pp. 391-418.

[26] Terra W.R., Evolution of digestive enzymes of insects, Annu. Rev. Entomol. 35 (1990) 181-200.

[27] Testa P.R., Silva A.N., Zucoloto F.S., Nutritional value of different pollen mixtures for Nannotrigona (Scaptotrigona) postica, J. Apic. Res. 20 (1981) 94-96.

[28] Zucoloto F.S., Valor nutritivo de pólens usados por diferentes espécies de abelhas para Nannotrigona (Scaptotrigona) postica (Hymenoptera, Apoidea), Rev. Bras. Biol. 35 (1975) 77-82.

[29] Zucoloto F.S., Nutritive value of some pollen substitutes for Nannotrigona (Scaptotrigona) postica, J. Apic. Res. 16 (1977) 59-61. 